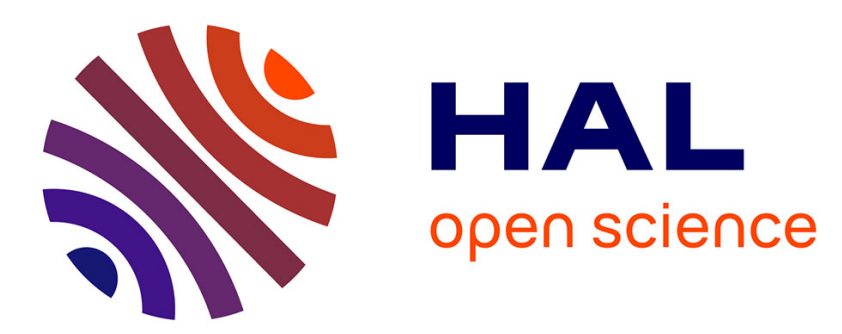

\title{
Interactions between earthworms, litter and trees in an old-growth beech forest
}

Jean-François Ponge, Nikola Patzel, Laurent Delhaye, Emmanuelle Devigne, Christine Levieux, Philippe Beros, Renaud Wittebroodt

\section{To cite this version:}

Jean-François Ponge, Nikola Patzel, Laurent Delhaye, Emmanuelle Devigne, Christine Levieux, et al.. Interactions between earthworms, litter and trees in an old-growth beech forest. Biology and Fertility of Soils, 1999, 29 (4), pp.360-370. 10.1007/s003740050566 . hal-00504812

\section{HAL Id: hal-00504812 \\ https://hal.science/hal-00504812}

Submitted on 21 Jul 2010

HAL is a multi-disciplinary open access archive for the deposit and dissemination of scientific research documents, whether they are published or not. The documents may come from teaching and research institutions in France or abroad, or from public or private research centers.
L'archive ouverte pluridisciplinaire HAL, est destinée au dépôt et à la diffusion de documents scientifiques de niveau recherche, publiés ou non, émanant des établissements d'enseignement et de recherche français ou étrangers, des laboratoires publics ou privés. 
1 INTERACTIONS BETWEEN EARTHWORMS, LITTER AND TREES IN AN OLD-GROWTH BEECH

2 FOREST

3

4 Jean-François Ponge, Nicolas Patzel, Laurent Delhaye, Emmanuelle Devigne, Christine Levieux,

$5 \quad$ Philippe Beros, and Renaud Wittebroodt

6

7 Museum National d'Histoire Naturelle, Laboratoire d'Ecologie Générale, 4 avenue du Petit-Château,

891800 Brunoy, France

9

10

Corresponding author: Jean-François Ponge, tel. +331 60479213, fax +331 60465009, E-mail:

11

jean-francois.ponge@wanadoo.fr

12 
Abstract Forty plots were selected in an old-growth beech forest (Biological Reserve of La Tillaie, Fontainebleau State Forest, France), to embrace the whole range of site conditions and phases of vegetation dynamics. Soils are sandy, thus the nutrient status of the topsoil is very poor except when trees have access to an underlying limestone layer. The study was focused on the role of calcium in the sustainability of the beech ecosystem. Calcium is mostly redistributed through leaf litter accretion and the activity of litter-consuming organisms, but other sources are fallen wood and uprooted mounds. In each of the 40 plots earthworm species were sampled, and measurements were taken in order to describe humus profiles, growth of adult trees, litter quantity and quality, and access to lime. Densities of soil-dwelling earthworms, calcium content of beech leaf litter, height of tallest trees and depth of the limestone layer were correlated, indicating a gradient of soil fertility which mainly results from long-term interactions between soil organisms and trees in varying geological conditions. Possible causal relationships and implications of calcium turnover for nature conservation were discussed in the light of existing knowledge.

Keywords Beech, Old-growth forest, Earthworms, Litter quality, Humus form

\section{Introduction}

The existence of reciprocal relationships between soil organisms and trees has long been recognized for symbiotic organisms such as mycorrhizal fungi (Frank 1892), and was used to explain the stability of forest (Perry et al. 1989) and heath (Read 1991) ecosystems. The idea that saprophagous fauna could be also involved in similar positive feed-back loops stemmed from the observation of common successional trends between soil animal communities, humus forms and vegetation (Miles 1985), with strong departures from expected ecosystem properties when some particular animal groups are absent for historical reasons (Muys and Lust 1992). In particular any improvement in soil fertility observed during forest succession, or over a range of climate and soil conditions, or following fertilization, is accompanied by the appearance of a more complex community of soil fauna, with more animal groups, in particular saprophagous macrofauna, where forest stands have a high productivity (Ponge et al. 1997). Among macrofauna, soil-dwelling earthworms are known to have a decisive 
influence on the development of mull humus forms (Bal 1982). Mull humus forms are characterized by fast litter turnover rates (Bocock et al. 1960), stable crumby structure (Monnier and Jeanson 1965), high nutrient availability (Muys et al. 1992), and deep rooting of trees (Meyer and Göttsche 1971). The positive action of earthworms upon the growth of trees has been experimentally verified, at least on very young plants (Marshall 1971), arising mainly from nitrogen-rich excreta (Lunt and Jacobson 1944). Conversely vegetation and soil may act on earthworm communities through litter and soil chemical compounds, which may selectively repel different species (Laverack 1960, 1961), and through nutrient levels, mostly of calcium, the requirements of which vary strongly from one species to another (Piearce 1972a, 1972b). Considering the above mentioned feed-back loops there is increasing evidence that even small changes in some soil, climate, and management conditions may lead to marked differences between sites, in particular in stand productivity, humus form, and regeneration (Ponge et al. 1998). We thus consider under the term site quality an assemblage of strongly related features such as soil biological activity (including humus form and faunal composition), tree growth, and nutrient availability (Ponge et al. 1997).

In old-growth forests the absence of human influence makes these sites more suitable for studying the long-term natural interplay between soil organisms and trees. The Biological Reserve of La Tillaie (Fontainebleau Forest, France), where European beech (Fagus sylvatica L.) invaded an old grazed oak [Quercus petraea (Mattus.) Liebl.] forest at least four centuries ago (Lemée 1990), displays a variety of site conditions, due to both the heterogeneity of the parent rock, especially the access to lime, and the natural course of forest dynamics (Koop and Hilgen 1987; Ponge and Delhaye 1995). Given the scarcity of calcium in the strongly acidic topsoil horizons of the Fontainebleau forest (Robin et al. 1981) we investigated the importance of this element in the observed relationships between earthworm communities, humus forms and vegetation. In particular the present study aimed at discerning trends which could probably be explained by feed-back processes.

\section{Methods}


The Biological Reserve of La Tillaie (34 ha) is characterized by the total neglect of forest management since the $17^{\text {th }}$ century (Koop 1989). The natural abundance of European beech in this site is not only due to its dominance in height over common oak and tolerance to shading at the seedling and sapling stage (Teissier du Cros et al. 1981), but also to the progressive invasion of European countries by beech since the last glaciation (Björkman and Bradshaw 1996). Even in places where beech is not at its optimum for growth and oak remains abundant, due to the more exacting nature of beech (Rehfuess et al. 1983), natural regeneration always favours beech (Ponge and Delhaye 1995). Exceptions to this scheme are places which have been invaded by a dense carpet of the bracken fern Pteridium aquilinum (L.) Kuhn, where beech regenerates only sporadically.

Soils are sandy (Robin and Duchaufour 1995). Fontainebleau sand is a very fine and pure quartz sand, with at most $1 \%$ and $3 \%$ clay and silt content, respectively (Robin et al. 1981), overlying a limestone or a sandstone layer (Robin 1970). Despite the sandy nature of topsoil horizons, and the acidifying nature of beech litter (Ovington 1953), soil biological activity is high on most of the study area, with a rapid disappearance of litter through white-rot and earthworm activity, and active mineralization of $\mathrm{C}$ and $\mathrm{N}$ in the $\mathrm{A}$ horizon (Lemée 1982). Oligomull, with an OL horizon and a moderately thin OF horizon (Brêthes et al. 1995), is the most frequently found humus form, with earthworm communities comprised of epigeic, anecic and endogeic species (Ponge and Delhaye 1995). The root system of beech ramifies both in topsoil horizons and deeper in the weathered limestone (Lemée 1978, and personal observations). Ground flora, mostly consisting of neutrocline species typical of the Fagetalia such as Melica uniflora Retz., Carex sylvatica Huds., Ruscus aculeatus L., Euphorbia amygdaloides L. (Lemée 1978), also comprises acidophiles (Pteridium aquilinum, Carex pilulifera L., Lonicera periclymenum L.) and nitrophiles (Scrophularia nodosa L., Solanum dulcamara L.). The presence of the latter group indicates the intense mineralization of nitrogen and the rapid turnover of the main nutrients despite the low pH of the topsoil (Lemée 1967; Lemée 1982). Only places with a harder unweathered limestone layer or with direct contact of sand on sandstone exhibit features of poorer soil biological activity (personal observations). In the former case (unweathered limestone) the most common humus form is dysmull, which is distinguished from 
oligomull by a thicker OF horizon (Brêthes et al. 1995), and a strong reduction in endogeic earthworm populations (Ponge and Delhaye 1995). In the latter case (sandstone) the total disappearance of endogeic and anecic earthworm species is responsible for the development of a dysmoder humus form, with a thick $\mathrm{OH}$ horizon. In places with poor access to lime the root system of beech is only superficial and ground vegetation is dominated by acidophilic species, bracken (Pteridium aquilinum) forming dense permanent patches in the zone with sand directly overlying sandstone (Ponge and Delhaye 1995).

Regeneration of beech occurs both by establishment of a new cohort within or by liberation of suppressed individuals following fall of overtopping branches. The canopy cover may be closed by crown enlargement, too, before regeneration or liberation of suppressed individuals can occur (Faille et al. 1984). Severe storms during the 1930's, in 1968 and in 1990, influenced the forest architecture by creating gaps (Koop and Hilgen 1987; Peltier et al. 1997). In most cases gaps created before 1980 are now filled up by beech in the pole phase. At the time of the first sampling (summer 1991) gaps opened by storms in 1990 were characterized by a poor herb layer. At the time of the last sampling (autumn 1995) most of them were characterized by a dense cover of blackberry (Rubus fruticosus $\mathrm{L}$. s.I.) or bracken, according to site conditions.

Forty plots were selected, embracing all aspects of geomorphology and forest dynamics which were present in the study site (Table 1). They were spread across the entire Reserve. The surface of the study plots was around 1a (100 m2). They were chosen after wandering freely around the Reserve and making up the whole sample so as to provide a balance between the geomorphological and sylvogenetical types which were present. Limestone or sandstone depth was measured with a soil probe at the center of each plot. For the sake of statistical analysis limestone depth was arbitrarily fixed at $230 \mathrm{~cm}$ when sandstone was reached within the prospected zone $(230 \mathrm{~cm})$ or when the thickness of blown sand exceeded the probe length. Selection of the study plots and classification according to phases of forest dynamics were achieved in June 1991.

Litter and humus 
The thickness of $\mathrm{OL}, \mathrm{OF}, \mathrm{OH}$, and $\mathrm{A}$ horizons, made of entire leaves, fragmented leaves, faeces of litter-dwelling animals, and underlying organo-mineral matter, respectively (Brêthes et al. 1995), was measured to the nearest $\mathrm{mm}$ after cutting a profile with a sharp knife through these horizons (six replicates in each plot). Darkness and colour of the $A$ horizon at $6 \mathrm{~cm}$ depth were described for the same six profiles using the Munsell囚 code (Anonymous 1990). The hue index, in the yellow-red scale, increases as the horizon colour changes from red to yellow, which has been identified as indicative of the passage from moder to mull humus forms (Ponge and Delhaye 1995). The value index decreases when the horizon becomes darker, indicating a higher content in organic matter due to a lower mineralization rate (Ponge and Delhaye 1995). The chroma index increases when the colour of the horizon becomes brighter. These features were measured for ten plots in July 1991 (indicated by a star in Table 1), then for thirty other plots in April 1992.

The areal weight of recently fallen beech leaf litter was measured just after main leaf fall at the end of November 1995 by collecting beech leaves in the inside of ten stainless steel rings $(15 \mathrm{~cm}$ diameter) randomly located near the center of each plot, and pressed onto the ground surface. Recently fallen beech leaves were collected in paper bags and immediately transported to the laboratory then dried in a fan-forced chamber to constant weight. They were weighed to the nearest $10^{-1} \mathrm{~g}$.

The calcium content of beech leaves was measured in each plot for the same litter samples. The ten air-dried samples were pooled for each plot, oven-dried at $60^{\circ} \mathrm{C}$ for $72 \mathrm{~h}$, then milled. A $200 \mathrm{mg}$ powder aliquot was incorporated into a mixture of $3 \mathrm{ml} 65 \% \mathrm{HNO}_{3}$ and $1 \mathrm{ml} 30 \% \mathrm{H}_{2} \mathrm{O}_{2}$; the mixture was boiled in teflon jars in a high-pressure micro-wave oven $\left(200-300{ }^{\circ} \mathrm{C}\right)$ for $30 \mathrm{mn}$. The calcium content was determined by flame atomic absorption in a Varian SpectrAA $300 \AA$ analyser after dilution in distilled water.

\section{Earthworms}

Earthworms were extracted by the formalin method (Raw 1959). Three waterings were performed at $10 \mathrm{mn}$ intervals, using $37 \%$ formalin diluted in tap water at $1 \%$, $2 \%$, and $3 \%$ concentration, 
respectively, after having removed the litter and aerial parts of ground vegetation. Six circular areas $1 / 4$ $\mathrm{m}^{2}$ each, randomly disposed around the center of each plot, were scrutinized for expelled earthworms. The amount of diluted formalin used was $3 \times 5$ I for each replicate. Given the sandy nature of the soil, even endogeic earthworms were easily recovered by this method, as had been verified previously by digging out the soil after applying the abovementioned procedure. Individuals were immediately killed and preserved in pure formalin, then transported to the laboratory. They were identified at the species level using Bouché (1972), Bouché (1976), and Sims and Gerard (1985). The total of adult and immature individuals was used to estimate earthworm densities per unit surface.

\section{Depth of the limestone layer}

At the center of each plot a soil probe was forced into the soil until hard rock was encountered (limestone of sandstone) or until the deepest level of sand was reached, i.e. $230 \mathrm{~cm}$ (total length of the probe). For direct contact with sandstone or when the lime- or sandstone layer was deeper than 230 $\mathrm{cm}$, this threshold was arbitrarily used as the depth of the limestone layer in order to avoid missing values. This measurement was performed on the forty plots in November 1995.

Height of mature trees

Some of the study plots were covered with full-grown trees, others were not. For estimating the potential growth in height of beech the height of the tallest individual present within or in the vicinity (not farther than $20 \mathrm{~m}$ ) of each studied plot was recorded to the nearest metre, using a Suunto Hypsometer ${ }^{\circledR}$ instrument. Measurement of the height of tallest mature trees was considered as an index of tree growth and stand productivity in even-aged forest stands (Falkengren-Grerup and Eriksson 1990). We tentatively extended this index to uneven-aged stands but only for estimating the maximum height of beech.

\section{Statistical analyses}


Correspondence analysis (Greenacre 1984) was performed on a matrix comprising 40 plots and 21 main (active) items including mean densities of the different earthworm species (11), humus features (7), height of the tallest tree, calcium content of beech litter, and mean areal weight of beech leaf litter. Depth of the limestone layer, phases of forest dynamics (7), and geomorphological features (3) were included as additional (passive) items. A modification of the method was used, for the purpose of easier interpretation of the graphs and better analysis of gradients. Data are reweighted (standard deviation $=1)$ and focused (mean $=20)$ and conjugate variables are created for each main item $(x$ transformed into $x^{\prime}=20-x$ ), thus each item is represented by two points on the graphs, the one for higher values, the other for lower values, without increasing the degrees of freedom (Ponge and Delhaye 1995). Whatever the nature of the data (countings, measurements, scores) each item has a similar weight (expressed by the mean) and a similar distance to the barycentre (expressed by the variance). Between these two points a gradient is displayed on the graphs. The longer is the distance between two conjugate points along an axis, the better the corresponding gradient contributes to the axis. Calculation of eigen values and vectors was performed on a 40 (plots) x 42 (variables) matrix.

The degree of association of each item with factorial axes was measured by the Bravais-Pearson correlation coefficient (Sokal and Rohlf 1995) using transformed data and factorial coordinates. Note that reweighting and focusing do not influence the calculation of the correlation coefficient. The threshold for significance of correlation was fixed at $5 \%$. Total and partial correlation coefficients between selected items were measured. For these calculations, earthworm densities were standardized using log $(x+1)$ transformation.

\section{Results}

Earthworm communities

Earthworm communities were composed of litter-dwelling (epigeic) and soil-dwelling lumbricid species. The latter category comprised both anecic and endogeic species (Sims and Gerard 1985). Anecic 
species move upwards in order to feed on litter, while endogeic species live in the organo-mineral soil (Bouché 1972). We found the following species:

Allolobophora chlorotica (Savigny 1826) (soil-dwelling, endogeic)

Aporrectodea caliginosa (Savigny 1826) (soil-dwelling, endogeic)

Aporrectodea longa (Ude 1885) (soil-dwelling, anecic)

Octolasion cyaneum (Savigny 1826) (soil-dwelling, endogeic)

Lumbricus terrestris Linnaeus 1758 (soil-dwelling, anecic)

Dendrobaena pygmaea (Savigny 1826) (litter-dwelling, epigeic)

Eisenia fetida (Savigny 1826) (litter-dwelling, epigeic)

Lumbricus castaneus (Savigny 1826) (litter-dwelling, epigeic)

Dendrodrilus rubidus (Savigny 1826) (litter-dwelling, epigeic)

Lumbricus eiseni Levinsen 1884 (litter-dwelling, epigeic)

Dendrobaena octaedra (Savigny 1826) (litter-dwelling, epigeic)

The species composition (Table 2) varied from purely epigeic (mostly on sand overlying sandstone), to both epigeic and anecic (mostly on sand overlying hard limestone), to a mixture of the three ecological categories (most other plots).

Relationships with other ecosystem features

Litter and humus features and height of tallest trees are presented in Table 3. Geomorphology and forest architecture have been already presented in Table 1. The bulk variation of all measured parameters was analysed by correspondence analysis. We included tree height as a main variable because we suspected symmetrical relationships with the other main variables. Forest architecture was included as an additional variable because it was considered to represent a classification for developmental (or recessional) stages of the beech ecosystem. Axis 1 extracted $18 \%$ of total inertia and displayed a clear trend of increasing site quality from the negative to the positive side. Other axes were of minor importance given our main objectives, thus points corresponding to plots and variables have been projected on axis 1 only (Figs. 1, 2, 3). 
Earthworm species were ordinated along axis 1, with higher densities of soil-dwelling species, both anecic (L. terrestris, A. longa) and endogeic (A. chlorotica, A. caliginosa, O. cyaneum), on the positive side (Fig. 1). Epigeic species did not display any significant association with this axis, higher as well as lower densities being placed not far from the origin. Tallest trees, calcium-rich litter, thin OF horizon, and yellowish A horizons were also placed on the positive side of axis 1, in a significant position (Fig . 2). Among passive variables, only geomorphology exhibited a significant association with axis 1 , shallow depth to limestone being placed in a significant position on the positive side, while sandstone was on the negative side (Fig. 3). Phases of forest dynamics and the presence hard limestone under sand did not seem to be associated with the global trend of increasing site quality depicted by axis 1 (Fig. 3).

The studied plots were accordingly distributed along axis 1 , with a clear departure of plots $C$ and $D$ from most other plots. These two plots were characterized by the presence of the limestone layer at a depth not exceeding 44 and $34 \mathrm{~cm}$, respectively, while other plots except $E$ (in third position on the positive side) had a deeper limestone layer. On the opposite side far from the origin we found plots sampled in the zone without any limestone layer (sandstone). In order to know whether axis 1 depicted a gradient of site quality or just distinguished $C$ and $D$ from other plots, we performed another correspondence analysis without $\mathrm{C}$ and $\mathrm{D}$. Despite minor changes in the ordering of plots and variables, the same trend of increasing site quality (earthworm abundance, tree height, richness of litter in $\mathrm{Ca}$, access to lime) was depicted. Thus we consider that the result which is presented here reflects the variation in site quality among the 40 studied plots. Axis 1 can be considered as a mathematical expression of the heterogeneity of the Biological Reserve, on the basis of the studied parameters.

We tried to analyse more precisely some of the relationships which had been displayed by correspondence analysis, focusing on densities of soil-dwelling earthworms (including anecic and endogeic species), depth of the limestone layer, calcium content of beech leaf litter, and height of tallest trees. There was a negative linear correlation between log-transformed soil-dwelling earthworm densities and the depth of the limestone layer $(r=-0.62, P<0.01$, Fig. 4), indicating that burrowing 
earthworm species were practically absent when the limestone layer was absent (depth arbitrarily fixed to $230 \mathrm{~cm}$ ) or deeper than $200 \mathrm{~cm}$. An exception was plot $\mathrm{N}$, which exhibited the highest abundance of soil-dwelling earthworms $\left(45.4\right.$ ind. $\left.\mathrm{m}^{-2}\right)$, despite more than $230 \mathrm{~cm}$ of sand overlying the limestone layer. Discarding plot $\mathrm{N}$ improved the correlation, as expected $(r=-0,75)$.

Similarly we observed a negative correlation between the calcium content of beech leaf litter and the depth of the limestone layer $(r=-0.64, P<0.01$, Fig. 5), and between the height of tallest trees and the depth of the limestone layer $(r=-0.45, P<0.01$, Fig. 6). Plot $\mathrm{N}$ had an expected little content in $\mathrm{Ca}$ in beech leaf litter, given the absence (or great depth) of the limestone layer, but had unexpectedly tall beech trees $(40 \mathrm{~m})$. There was a significant positive correlation between densities of soil-dwelling earthworms and height of tallest trees $(r=-0.54, P<0.01$, Fig. 7). Plot $N$ had both high soil-dwelling earthworm densities and tall trees, thus following the global trend depicted by axis 1 of the correspondence analysis. Discarding plot $\mathrm{N}$ did not affect the significance level of the correlation coefficients.

Calculation of partial correlation coefficients according to procedures by Sokal and Rohlf (1995) may help to better discern direct from indirect relationships within a set of highly correlated variables. When other variables were fixed, correlations remained significant between the depth of the limestone layer and densities of soil-dwelling earthworms $\left(r_{\text {part }}=-0.54, P<0.01\right)$, between the depth of the limestone layer and the calcium content of beech leaf litter $\left(r_{\text {part }}=-0.57, P<0.01\right)$, and between densities of soil-dwelling earthworms and height of tallest trees $\left(r_{\text {part }}=0.38, P<0.05\right)$. Partial correlation coefficients between the calcium content of beech leaf litter and densities of soil-dwelling earthworms $\left(r_{\text {part }}=-0.06\right)$ and between the calcium content of beech leaf litter and height of tallest trees $\left(r_{\text {part }}=-\right.$ 0.17 ) were insignificant at the 0.05 level.

\section{Discussion}

Total and partial correlation coefficients indicated a significant correlation between the depth of the limestone layer and the Ca-content of beech litter. The positive influence of Ca-richness of the soil on 
the Ca-content of beech foliage and litter has been well-established (Staaf 1987). Calcium uptake by trees is often considered as luxury consumption (Tamm 1964), the Ca-content of foliage reflecting more the nutrient status of the site than the calcium requirements of the trees. Similarly, the calcium content of phloem and roots of beech reflects the mineral richness of the soil (Rehfuess et al. 1983). Contrary to what had been claimed by Robin (1970) and Lemée and Bichaut (1971) on the basis of measurements made on the same site (but on a fewer number of plots, none of them being on sandstone), we observed a strong variation in the Ca-content of beech leaf litter, which ranged from $0.7 \%$ to $1.6 \%$, significantly correlated with the depth of the limestone layer (Fig. 5). The depth of the limestone layer seems to control the availability of calcium to trees, probably via a limit to the extension in depth of the root system of European beech, i.e. $1.8 \mathrm{~m}$ according to Stone and Kalisz (1991). However, this does not explain why the observed relationship was i) linear (Fig. 5), ii) independent of the fact that the limestone layer was weathered or not (unweathered limestone near the origin, Fig. 3).

The better link of densities of soil-dwelling earthworms with the depth of the limestone layer $(r=-$ 0.62, $P<0.01)$, than with the calcium content of beech leaf litter $(r=0.36, P<0.05)$ seems at first sight surprising, soil-dwelling earthworms (more especially endogeic species) being known for their high food calcium requirements (Piearce 1972a). Despite that, large mesh-size litter-bag experiments with beech leaves strongly differing in their Ca content (coming from mull, moder, and mor sites) failed to reveal any preference order in their consumption by L. terrestris (Staaf 1987). Most studies on litter palatability to earthworms did not point out the calcium content of foliage for explaining the observed preferences (Lofty 1974). Rather, the content of astringent phenolics, which is controlled by base richness of the soil (Muller et al. 1987), is known to be negatively correlated with the palatability of leaf litter to earthworms (Hendriksen 1990). Even if the calcium content of litter is not directly perceived by these animals in choice experiments, calcium-requiring species such as soil-dwelling earthworms are unable to survive on a calcium-poor litter (Satchell 1980), as this is the case when the limestone layer is absent or lower than the root system of beech (Fig. 5). In order to fulfill their calcium requirements directly from the limestone layer, these animals have to burrow as deep as 40 to $100 \mathrm{~cm}$ (Table 1 ), which we think possible, given the present knowledge on the deep burrowing activity of $L$. terrestris (Lee and Foster 1991). This could be another process linking earthworm abundance to depth of the 
limestone layer. Rather puzzling is the case of plot $\mathrm{N}$, which is characterized by high earthworm abundance and tall trees, despite deep $(<2.3 \mathrm{~m})$ limestone layer and poor Ca-content of beech litter (Tables 2, 3). This old gap (not filled by beech since at least 10 years, contrary to other studied gaps without bracken) displays a luxuriant field layer made of blackberry and several grasses, which probably furnish a litter of a better nutritive value than beech, despite poor site conditions.

Another mechanism, although not covered by our sampling design, could also explain the observed influence of limestone depth. When beech trees are uprooted by wind, a large part of the root system is exposed, together with attached soil (Brown 1977). The amount of limestone thus present as small islands at the ground surface can be roughly considered proportional to the depth of the limestone layer (given a constant rate of windthrowal), and may help to explain this phenomenon. The Ca-rich excavated earth can be further redistributed from these islands through the wandering activity of soilconsuming animals, at least over a distance of a few metres (Judd and Mason 1995). The application of lime as powder to forest soils is known to increase the abundance of existing earthworm species (Ammer and Makeschin 1994) or to allow colonization by other, more exacting species (Robinson et al. 1992). In the studied site the same fertilizing effect could be achieved by the natural uprooting of trees, at least when the limestone layer is shallow. Cord-forming fungal mycelia could also contribute to this horizontal movement of mineral elements (Thompson 1984). The release of Ca from decomposing beech leaf litter, the content of which is correlated with depth of the limestone layer (Fig. 5), can be considered, too, as fertilizing the topsoil, being further redistributed through animal movements and growth of fungal mycelia. Thus we can suspect both horizontal and vertical redistribution of calcium under the influence of soil organisms.

The third point which has been documented in the present study is the positive correlation between tree height and the abundance of soil-dwelling species. Although the height of tallest trees can be considered a good indicator of site quality (Ponge et al. 1997), its relationship with earthworm communities can at first sight be considered indirect. Nevertheless, some pot experiments have demonstrated the positive influence of earthworms on the growth of tree seedlings (Marshall 1971; Haimi et al. 1992; Pashanasi et al. 1992), and a hormonal influence on plant nutrition of cast humic 
compounds has even been suspected (Dell'Agnola and Nardi 1987), athough the latter result was not confirmed by Haimi and Einbork (1992).

The observed relationships between soil-dwelling earthworms and litter quality are most probably symmetrical. Most calcium requirements of these animals are fulfilled by leaf litter consumption or by the consumption of soil locally enriched in Ca by litter decomposition (Piearce 1972b; Bouché et al. 1983). In an unmanaged forest, islands of excavated deep soil horizons and decaying logs are additional sources of calcium. In turn, earthworms stimulate soil biological activity (Pashanasi et al. 1992; Loranger et al. 1998) and, among other biological processes, litter decomposition (Spiers et al. 1986; Staaf 1987). Soil-dwelling earthworms are thus involved in a positive feed-back loop, embracing both growth of trees and quality of litter.

Considering the abovementioned points, the following scheme can be considered as most realistic in the light of existing literature:

Access to lime

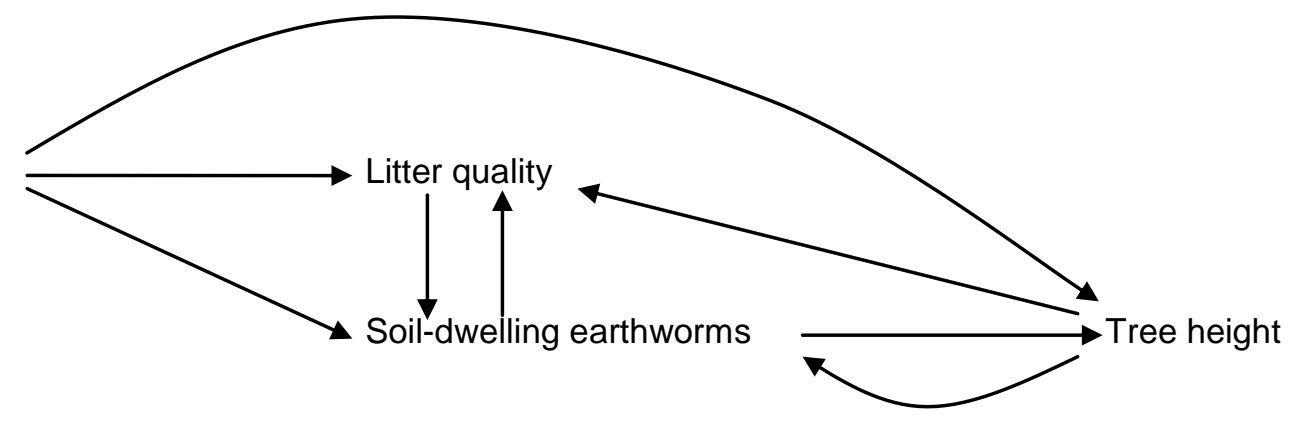

The authors are aware of the fact that, despite its prominent importance in soil foodwebs (Cromack et al. 1977) and control of soil acidity (Spiers et al. 1986), calcium is not the only nutrient involved in the studied relationships, in particular in those involving tree growth and litter quality. Although the present study was focused on this element it should be underlined that access to lime through roots, animals, or fungi, means also access to several nutrients which are constantly present or immobilized or in a more available form in calcareous rocks, such as magnesium, potassium and phosphorus, respectively (Brady 1984). 
The existence of positive feed-back loops would normally imply that ecological conditions became unequally distributed in the study site in the course of time (Ashby 1956). Sites with better geological conditions would have acted as attractors for tree growth, nutrient content of litter, densities of soildwelling earthworms, and other ecological features associated with higher soil fertility (Ponge et al. 1997). This was most probably the case for plots $C$ and $D$ (Figs. 1, 2, 3). To test accurately of this hypothesis it would be necessary to take repeated measurements on a much higher number of plots, randomly chosen over the whole study site.

\section{Acknowledgements}

This study was undertaken with help of financial support from the French Ministry of the Environment (EGPN-Committee) and later from the GIP-ECOFOR organization, which are greatfully acknowledged. Thanks are due to the French National Office of Forests for free access to the site for sampling, and additional financial support when starting the study. Calcium determinations were performed at the Polytechnicum Institute of Zürich (Switzerland), which is acknowledged for access to analytical equipment. Several people should be acknowledged for their kind assistance during selection of sites and field measurements, more especially Sandrine Salmon and Pierre Arpin.

\section{References}

Ammer S, Makeschin F (1994) Auswirkungen experimenteller saurer Beregnung und Kalkung auf die Regenwurmfauna (Lumbricidae, Oligochaeta) und die Humusform in einem Fichtenaltbestand (Höglwaldexperiment). Forstwiss Centralbl 113: 70-85

Anonymous (1990) Munsell® soil color charts. Munsell Color, Macbeth Division of Kollmorgen Instruments Corporation, Baltimore

Ashby WR (1956) Introduction to cybernetics. Chapman and Hall, London 
Bal L (1982) Zoological ripening of soils. PUDOC, Wageningen

3

Björkman L, Bradshaw R (1996) The immigration of Fagus sylvatica L. and Picea abies (L.) Karst. into a natural forest stand in southern Sweden during the last 2000 years. J Biogeogr 23: 235-244

Bocock KL, Gilbert O, Capstick CK, Twinn DC, Waid JS, Woodman M.J (1960) Changes in leaf litter when placed on the surface of soils with contrasting humus types. I. Losses in dry weight of oak and ash leaf litter. J Soil Sci 11: 1-9

Bouché MB (1972) Lombriciens de France. Écologie et systématique. INRA, Paris

Bouché MB (1976) Contribution à la stabilisation de la nomenclature des Lumbricidae, Oligochaeta. I. Synonymies et homonymies d'espèces du Bassin Parisien. B Mus Nat Hist Nat 354: 81-87

BrownJL (1977) Étude de la perturbation des horizons du sol par un arbre qui se renverse et de son impact sur la pédogénèse. Can J Soil Sci 57: 173-186

Cromack KJr, Sollins P, Todd RL, Crossley DAJr, Fender WM, Fogel R, Todd AW (1977) Soil microorganism-arthropod interactions: fungi as major calcium and sodium sources. In: Mattson WJ (ed) The role of arthropods in forest ecosystems. Springer-Verlag, New York, pp 78-84

Bouché MB, Rafidison Z, Toutain F (1983) Étude de l'alimentation et du brassage pédo-intestinal du lombricien Nicodrilus velox (Annelida, Lumbricidae) par l'analyse élémentaire. Rev Ecol Biol Sol 20: 49-75

Brêthes A, Brun JJ, Jabiol B, Ponge JF, Toutain F (1995) Classification of forest humus forms: a French proposal. Ann Sci Forest 52: 535-546 
Dell'Agnola G, Nardi S (1987) Hormone-like effect and enhanced nitrate uptake induced by depolycondensed humic fractions obtained from Allolobophora rosea and A. caliginosa faeces. Biol Fert Soils 4: 115-118

Faille A, Lemée G, Pontailler JY (1984) Dynamique des clairières d'une forêt inexploitée (réserves biologiques de la forêt de Fontainebleau). II. Fermeture des clairières actuelles. Acta Oecol Oecol Gen 5: 181-199

Falkengren-Grerup U, Eriksson H (1990) Changes in soil, vegetation and forest yield between 1947 and 1988 in beech and oak sites of southern Sweden. Forest Ecol Manag 38: 37-53

Frank AB (1892) Die Ernährung der Kiefer durch ihre Mykorrhiza-Pilze. Ber Deut Bot Ges 10: 577-583

Greenacre MJ (1984) Theory and applications of correspondence analysis. Academic Press, London

Haimi J, Einbork M (1992) Effects of endogeic earthworms on soil processes and plant growth in coniferous forest soil. Biol Fert Soils 13: 6-10

Haimi J, Huhta V, Boucelham M (1992) Growth increase of birch seedlings under the influence of earthworms. A laboratory study. Soil Biol. Biochem. 24: 1525-1528

Hendriksen NB (1990) Leaf litter selection by detritivore and geophagous earthworms. Biol Fert Soils 10: $17-21$

Judd KW, Mason CF (1995) Earthworm populations of a restored landfill site. Pedobiologia 39: 107115

Koop H (1989) Forest dynamics. Springer-Verlag, Berlin 
1 Koop H, Hilgen P (1987) Forest dynamics and regeneration mosaic shifts in unexploited beech (Fagus sylvatica) stands at Fontainebleau (France). Forest Ecol Manag 20: 135-150

Laverack MS (1960) Tactile and chemical perception in earthworms. I. Responses to touch, sodium chloride, quinine and sugars. Comp Biochem Physiol 1: 155-163

6

7

Laverack MS (1961) Tactile and chemical perception in earthworms. II. Responses to acid pH solutions. Comp Biochem Physiol 2: 22-34

Lee KE, Foster RC (1991) Soil fauna and soil structure. Aust J Soil Res 29: 745-775

Lemée G (1967) Investigations sur la minéralisation de l'azote et son évolution annuelle dans des humus forestiers in situ. Oecol Plant 2: 285-324

Lemée G (1978) La hêtraie naturelle de Fontainebleau. In: Lamotte M, Bourlière F (eds) Problèmes d'écologie: structure et fonctionnement des écosystèmes terrestres, Masson, Paris, pp 75-128

Lemée G (1982) Recherches sur les écosystèmes des réserves biologiques de la forêt de Fontainebleau. VIII. Éléments du bilan d'azote du sol. Rev Ecol Biol Sol 19: 485-499

Lemée G (1990) Les réserves biologiques de la Tillaie et du Gros-Fouteau en forêt de Fontainebleau, écocomplexes climaciques. B Soc Bot Fr Lett 137: 47-62

Lemée G, Bichaut N (1971) Recherches sur les écosystèmes des réserves biologiques de la forêt de Fontainebleau. I. Production de litière et apport au sol d'éléments minéraux majeurs. Oecol Plant 6: $133-149$

Lofty JR (1974) Oligochaetes. In: Dickinson CH, Pugh GJF (eds) Biology of plant litter decomposition, vol. 2. Academic Press, London, pp 467-488 
Loranger G, Ponge JF, Blanchart E, Lavelle P (1998) Impact of earthworms on the diversity of microarthropods in a vertisol (Martinique). Biol Fert Soils 27: 21-26

Lunt HA, Jacobson HGM (1944) The chemical composition of earthworm casts. Soil Sci 58: 367-375

Marshall VG (1971) Effects of soil arthropods and earthworms on the growth of black spruce. In: Organismes du sol et production primaire, Proc $4^{\text {th }}$ Coll Soil Zool Com Int Soc Soil Sci, Dijon, France, 1970. INRA, Paris, pp 109-117

Meyer FH, Göttsche D (1971) Distribution of root tips and tender roots of beech. In: Ellenberg H (ed) Ecological studies. Analysis and synthesis, vol. 2. Springer-Verlag, Berlin, pp 47-52

Miles J (1985) Soil in the ecosystem. In: Fitter AH, Atkinson D, Read DJ, Usher MB (eds) Ecological interactions in soil. Plants, microbes and animals. Blackwell Scientific Publications, Oxford, pp 407427

Monnier G, Jeanson C (1965) Studies on the stability of soil structure: influence of moulds and soil fauna. In: Hallsworth EG, Crawford DV (eds) Experimental pedology. Butterworths Scientific Publications, London, pp 244-254

Muller RN, Kalisz PJ, Kimmerer TW (1987) Intraspecific variation in production of astringent phenolics over a vegetation-resource availability gradient. Oecologia 72: 211-215

Muys B, Lust N (1992) Inventory of the earthworm communities and the state of litter decomposition in the forests of Flanders, Belgium, and its implications for forest management. Soil Biol Biochem 24: $1677-1681$

Muys B, Lust N, Granval P (1992) Effects of grassland afforestation with different tree species on earthworm communities, litter decomposition and nutrient status. Soil Biol Biochem 24: 1459-1466 
Ovington JD (1953) Studies on the development of woodland conditions under different trees. I. Soil pH. J Ecol 41: 13-34

Pashanasi B. Melendez G, Szott L, Lavelle P (1992) Effect of inoculation with the endogeic earthworm Pontoscolex coreruthrus (Glossoscolecidae) on $\mathrm{N}$ availability, soil microbial biomass and the growth of three tropical fruit tree seedlings in a pot experiment. Soil Biol Biochem 24: 1655-1659

Peltier A, Touzet MC, Armengaud C, Ponge JF (1997) Establishment of Fagus sylvatica and Fraxinus excelsior in an old-growth beech forest. J Veg Sci 8: 13-20

Perry DA, Amaranthus MP, Borchers JG, Borchers SL, Brainerd RE (1989) Bootstrapping in ecosystems. Bioscience 39: 230-237

Piearce TG (1972a) The calcium relations of selected Lumbricidae. J Anim Ecol 41: 167-188

Piearce TG (1972b) Acid intolerant and ubiquitous Lumbricidae in selected habitats in North Wales. J Anim Ecol 41: 397-410

Ponge JF, André J, Zackrisson O, Bernier N, Nilsson MC, Gallet C (1998) The forest regeneration puzzle: biological mechanisms in humus layer and forest vegetation dynamics. BioScience 48: 523530

Ponge JF, Arpin P, Sondag F, Delecour F (1997) Soil fauna and site assessment in beech stands of the Belgian Ardennes. Can J Forest Res 27: 2063-2064

Ponge JF, Delhaye L (1995) The heterogeneity of humus profiles and earthworm communities in a virgin beech forest. Biol Fert Soils 20: 24-32

Raw F (1959) Estimating earthworm populations by using formalin. Nature 184: 1661-1662 
Read DJ (1991) Mycorrhizas in ecosystems. Experientia 47: 376-391.

Rehfuess KE, Flurl H, Franz F, Raunecker E (1983) Growth patterns, phloem nutrient contents and root characteristics of beech (Fagus sylv. L.) on soils of different reaction. In: Ulrich B, Pankrath J (eds) Effects of accumulation of air pollutants in forest ecosystems. D. Reidel Publishing Company, Dordrecht, pp 359-375

Robin AM (1970) Contribution à l'étude du processus de podzolisation sous forêt de feuillus. Sci Sol [1970-1]: 63-83

Robin AM, Duchaufour P (1995) La typologie des stations forestières du Massif de Fontainebleau. Ecologie 26: 159-168

Robin AM, Guillet B, Deconinck F (1981) Genèse et évolution des sols podzolisés sur affleurements sableux du Bassin Parisien. B Ass Fr Etude Sol [1981]: 315-329

Robinson CH, Piearce TG, Ineson P, Dickson DA, Nys C (1992) Earthworm communities of limed coniferous soils: field observations and implications for forest management. Forest Ecol Manag 55: $117-134$

Satchell JE (1980) Potential of the Silpho Moor experimental birch plots as a habitat for Lumbricus terrestris. Soil Biol Biochem 12: 317-323

Sims RW, Gerard BM (1985) Earthworms. Keys and notes for the identification of the species. Brill and Backhuys, London

Sokal RR, Rohlf FJ (1995) Biometry. The principles and practice of statistics in biological research, $3^{\text {rd }}$ edition. W.H. Freeman and Company, New York 
Spiers GA, Gagnon D, Nason GE, Packee EC, Lousier JD (1986) Effects and importance of indigenous earthworms on decomposition and nutrient cycling in coastal forest ecosystems. Can J Forest Res 16: 983-989

Staaf $\mathrm{H}$ (1987) Foliage litter turnover and earthworm populations in three beech forests of contrasting soil and vegetation types. Oecologia $72:$ 58-64

Stone EL, Kalisz PJ (1991) On the maximum extent of tree roots. Forest Ecol Manage 46: 59-102

Tamm CO (1964) Determination of nutrient requirements of forest stands. Int Rev Forestry Res 1: 115170.

Teissier du Cros E, Le Tacon F, Nepveu G, Pardé J, Perrin R, Timbal J (1981) Le hêtre. INRA, Paris

Thompson W (1984) Distribution, development and functioning of mycelial cord systems of decomposer basidiomycetes of the deciduous woodland floor. In Jennings DH, Rayner ADM (eds) The ecology and physiology of the fungal mycelium. Cambridge University Press, Cambridge, pp $185-214$ 
Table 1. List of the 40 studied plots, with indications on geomorphology and phases of forest dynamics, classified according to axis 1 coordinates of correspondence analysis.

Plot Zone $\quad$ Forest dynamics Limestone/sandstone depth

\begin{tabular}{|c|c|c|c|}
\hline AH & Sandstone & Bracken & sandstone $142 \mathrm{~cm}$ \\
\hline AF & Sandstone & Crown enlargement & $>230 \mathrm{~cm}$ \\
\hline Al & Sandstone & Mature phase & $>230 \mathrm{~cm}$ \\
\hline $\mathbf{Q}\left({ }^{\star}\right)$ & & Old gap & $83 \mathrm{~cm}$ \\
\hline $\mathbf{S}\left(^{*}\right)$ & & Gap 1990 & $65 \mathrm{~cm}$ \\
\hline$A G$ & Sandstone & Crown enlargement & $>230 \mathrm{~cm}$ \\
\hline $\mathrm{AE}$ & Sandstone & Mature phase & sandstone $140 \mathrm{~cm}$ \\
\hline AC & Hard limestone & Pole phase & $181 \mathrm{~cm}$ \\
\hline G & Sandstone & Bracken & sandstone $50 \mathrm{~cm}$ \\
\hline H & Sandstone & Pole phase & sandstone $62 \mathrm{~cm}$ \\
\hline $\mathbf{M}^{\prime}\left({ }^{*}\right)$ & & le phase & $156 \mathrm{~cm}$ \\
\hline N" & & Pole phase & $180 \mathrm{~cm}$ \\
\hline AB & Hard limestone & Gap 1990 & $164 \mathrm{~cm}$ \\
\hline U & & Old gap & $144 \mathrm{~cm}$ \\
\hline $\mathbf{J}$ & & Pole phase & $160 \mathrm{~cm}$ \\
\hline $\mathbf{K}\left({ }^{*}\right)$ & & Mature phase & $129 \mathrm{~cm}$ \\
\hline V & Hard limestone & Relict oak & $138 \mathrm{~cm}$ \\
\hline $\mathbf{T}\left(^{*}\right)$ & & Mature phase & $100 \mathrm{~cm}$ \\
\hline A & & Gap 1990 & $80 \mathrm{~cm}$ \\
\hline $\mathbf{K}^{\prime}\left({ }^{*}\right)$ & & Gap 1990 & $67 \mathrm{~cm}$ \\
\hline $\mathbf{L}\left({ }^{*}\right)$ & & Pole phase & $77 \mathrm{~cm}$ \\
\hline 0 & & Gap 1990 & $223 \mathrm{~cm}$ \\
\hline AA & Hard limestone & Pole phase & $149 \mathrm{~cm}$ \\
\hline AD & Sandstone & Crown enlargement & $167 \mathrm{~cm}$ \\
\hline $\mathbf{Y}$ & Hard limestone & Mature phase & $106 \mathrm{~cm}$ \\
\hline M & & Pole phase & $97 \mathrm{~cm}$ \\
\hline $\mathbf{Z}$ & Hard limestone & Crown enlargement & $125 \mathrm{~cm}$ \\
\hline $\mathbf{X}$ & Hard limestone & Pole phase & $97 \mathrm{~cm}$ \\
\hline $\mathbf{R}$ & & Crown enlargement & $100 \mathrm{~cm}$ \\
\hline B & & Pole phase & $54 \mathrm{~cm}$ \\
\hline $\mathbf{N}^{\prime}\left({ }^{*}\right)$ & & Old gap & $184 \mathrm{~cm}$ \\
\hline I $\left(^{*}\right)$ & & Pole phase & $101 \mathrm{~cm}$ \\
\hline W & Hard limestone & Old gap & $127 \mathrm{~cm}$ \\
\hline AJ & & Pole phase & $88 \mathrm{~cm}$ \\
\hline $\mathbf{P}$ & & Mature phase & $96 \mathrm{~cm}$ \\
\hline $\mathbf{N}\left({ }^{*}\right)$ & & Old gap & $>230 \mathrm{~cm}$ \\
\hline $\mathbf{F}$ & & Gap 1990, relict oak & $60 \mathrm{~cm}$ \\
\hline $\mathbf{E}$ & & Pole phase & $44 \mathrm{~cm}$ \\
\hline C & & Mature phase & $44 \mathrm{~cm}$ \\
\hline D & & Gap 1990 & $34 \mathrm{~cm}$ \\
\hline
\end{tabular}

Zones were delineated according to maps by Bouchon et al. (1973) and personal observations: without any indication = sand overlying weathered limestone; hard limestone = blown sand overlying unweathered limestone.

Forest dynamics: pole phase $=$ trees growing actively in patches, generally issuing from gaps opened before 1980; mature phase = full-grown trees in groups of three or more; old gap = gap opened between 1968 and 1990; bracken = gaps invaded by Pteridium aquilinum .

Limestone/sandstone depth $=$ depth of the limestone layer unless otherwise indicated.

$\left({ }^{*}\right)=$ sites investigated in 1991 for the description of humus profiles and earthworm communities. Other sites were investigated in 1992. 
Table 2. Earthworm densities (ind. $\mathrm{m}^{-2}$ ) in the 40 studied plots, classified according to axis 1 coordinates of correspondence analysis.

\section{AH}

AF 2.0

Al

$\begin{array}{ll}\mathbf{Q} & 6.7 \\ \mathbf{S} & 1.3\end{array}$

AG 1.3

$A E$

AC $\quad 10.0$

G $\quad 2.7$

H $\quad 0.7$

$\begin{array}{ll}\mathbf{M}^{\prime} \quad 2.0 & 0.7\end{array}$

N"

AB $\quad 10.7$

U $\quad 3.3$

$\begin{array}{ll}\mathbf{J} & 1.3\end{array}$

$\begin{array}{ll}\text { K } & 0.7\end{array}$

V $\quad 0.7$

$\begin{array}{ll}\text { T } & 13.3\end{array}$

A

K'

L

\begin{tabular}{ll} 
O & 3.3 \\
\hline
\end{tabular}

AA 0.7

AD 4.0

$\begin{array}{ll}\text { Y } & 2.0\end{array}$

M

$\begin{array}{ll}\mathbf{Z} & 1.3 \\ \mathbf{X} & 6.0\end{array}$

R 4.0

B

N'

I 2.0

W 4.0

AJ 0.7

$\begin{array}{ll}\text { P } & 0.7\end{array}$

$\begin{array}{ll}\text { N } & 0.7\end{array}$

F

E

C

D

\section{7}

4.0

9.3

0.7

0.7

2.0

0.7

8.0

4.0

$0.7 \quad 18.0$

6.3

$6.7 \quad 9.3$

$\begin{array}{ll}0.7 & 17.3\end{array}$

$\begin{array}{ll}6.7 & 1.3\end{array}$

$\begin{array}{ll}2.0 & 0.7\end{array}$

$3.3 \quad 1.3$

0.7

4.0

$1.3 \quad 2.0$

$5.3 \quad 4.0$

$3.3 \quad 8.7$

$9.3 \quad 2.0$

$6.7 \quad 8.0$

$6.0 \quad 13.3$

12.0

$2.7 \quad 5.3$

$28.0 \quad 2.7$

$12.0 \quad 3.3$

$8.0 \quad 6.7$

$10.7 \quad 17.3$

$6.0 \quad 4.7$

4.7

7.3

4.0

1.3
1.3

1.3

1.3

2.7

5.3

0.7

$\begin{array}{ll} & 0.7 \\ 0.7 & 1.3\end{array}$

0.7

6.0

1.3

9.3

$0.7^{4.0}$

0.7

3.3

0.7

2.0

3.3

2.0

3.3

3.3

4.7

0.7

0.7

$\begin{array}{ll}2.0 & 0.7\end{array}$

$0.7 \quad 2.0$

$9.3 \quad 0.7$

$1.3 \quad 6.0$

4.0

$0.7 \quad 2.0$

1.3

4.0
$0.7 \quad 4.0$

7.3

8.0

13.3

8.7

7.3

5.3

$0.7 \quad 10.0$

30.7

7.3

$1.3 \quad 10.0-1.3$

$\begin{array}{lll}1.3 & 10.0 & 2.7 \\ 15.3 & 10.0 & 7.3\end{array}$

$\begin{array}{lll}2.0 & 20.7 & 6.0\end{array}$ 
Table 3. Litter and humus features, and height of tallest trees in the 40 studied plots, classified according to axis 1 coordinates of correspondence analysis. Nomenclature of $\mathrm{OL}, \mathrm{OF}, \mathrm{OH}$, and $\mathrm{A}$ follow Brêthes et al. (1995). Hue, value, and chroma refer to Munsell囚 code (Anonymous 1990).

Litter Litter

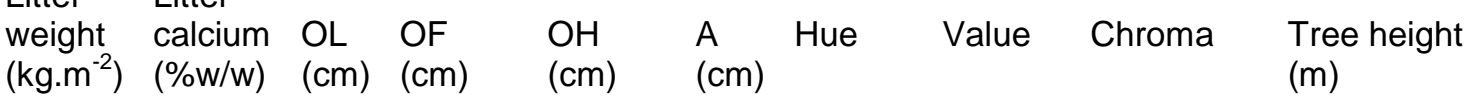

10

\section{AH 2.27}

AF 2.18

Al 2.20

Q $\quad 1.91$

S 2.01

AG 2.10

AE 2.13

AC $\quad 1.97$

G $\quad 1.44$

H 1.92

$\begin{array}{ll}\mathbf{M}^{\prime} & 2.45\end{array}$

N" 2.40

AB 2.03

U 2.39

J 2.25

K 2.31

V 2.02

T
A

A 2.09

K' 1.85

L 2.21

O 2.24

AA 2.25

AD 1.88

Y 2.33

\begin{tabular}{l} 
M $\quad 2.17$ \\
\hline
\end{tabular}

$\begin{array}{ll}\text { Z } & 2.41\end{array}$

\begin{tabular}{l}
$\mathbf{X} \quad 2.29$ \\
\hline
\end{tabular}

R 2.14

B 2.23

$\begin{array}{ll}\text { N' }^{\prime} & 2.21\end{array}$

I 2.18

W 1.79

AJ 2.36

$\begin{array}{ll}\text { P } & 2.23 \\ \text { N }\end{array}$

N 1.78

F 1.99

E 2.26

C 2.09

D $\quad 1.85$

\subsection{8}

1.09

1.13

1.09

1.22

0.96

0.92

0.77

1.12

1.12

1.26

1.18

0.97

1.05

1.29

1.21

1.32

1.08

1.17

1.26

1.32

1.21

1.29

1.09

1.19

1.25

1.32

1.23

1.18

1.17

1.14

1.39

1.55

1.28

1.29

0.68

1.36

1.45

1.52

1.36

\subsection{2 .2}

3.03 .2

0.61 .2

1.02 .8

1.43 .5

1.82 .1

2.52 .8

3.31 .7

1.81 .5

$\begin{array}{ll}0.60 .8 & 1.0 \\ 1.82 .6 & 2.4\end{array}$

$\begin{array}{lll}3.23 .8 & 0.7 & 4.210 .\end{array}$

$4.3 \quad 1.3$

29

$\begin{array}{ll}0.1 & 7.25 .0 \\ 0.1 & 6.510 .0 \\ 1.0 & 7.25 .0\end{array}$

$\begin{array}{ll}1.0 & 7.25 .0 \\ 0.5 & 2.18 .3\end{array}$

$4.3^{3.3} 1.7^{1.3}$

24

1.0

2.18 .3
4.56 .7

$\begin{array}{ll}2.7 & 1.7 \\ 2.9 & 1.5\end{array}$

29

41

$0.4 \quad 6.010 .0$

$5.0^{1.5}$

$\begin{array}{rrr}1.71 .0 & 0.3 \quad 5.310 .0 \\ 2.01 .5 & 0.0 & 6.010 .0\end{array}$

$\begin{array}{lll}2.82 .5 & 0.0 & 7.710 .0\end{array}$

$\begin{array}{lll}1.02 .6 & 0.8 & 4.010 .0\end{array}$

1.14 .0

1.52 .4

0.0

2.81 .7

0.72 .4

1.12 .8

0.60 .8

1.81 .8

0.51 .0

1.51 .7

1.32 .3

0.7

$\begin{array}{llll}10.7 & 10.0 & 3.3 & 1.0\end{array}$

0.1

5.710 .0

4.69 .2

$\begin{array}{ll}4.8 & 2.3\end{array}$

$\begin{array}{ll}5.0 & 1.7\end{array}$

$\begin{array}{lll}3.7 & 1.3 & 34\end{array}$

1.21 .3

$0.8 \quad 3.210 .0$

$3.8^{4.3} 2.0^{2.0}$

2.01.

0.71 .0

2.71 .3

1.52 .8

2.22.

1.70 .4

1.02 .0

0.80 .5

1.01 .8

1.30 .2

2.71 .2

1.70 .8

0.80 .3

0.0510 .0

9.310 .0

$4.0 \quad 2.5$

$3.7 \quad 1.0$

$\begin{array}{ll}4.0 & 1.3\end{array}$

$\begin{array}{ll}5.0 & 1.7\end{array}$

$4.0 \quad 1.3$

$0.0 \quad 5.510 .0$

0.0

8.210 .0

$\begin{array}{ll}5.0 & 2.7\end{array}$

$\begin{array}{lll}0.0 & 11.2 & 10.0\end{array}$

$3.0 \quad 1.0$

$4.7 \quad 1.3$

$\begin{array}{ll}5.0 & 2.7\end{array}$

$\begin{array}{ll}5.3 & 1.7 \\ 3.2 & 1.7\end{array}$

$\begin{array}{ll}3.2 & 1.7\end{array}$

$\begin{array}{ll}4.2 & 2.7\end{array}$

$3.7 \quad 1.0$

$\begin{array}{ll}5.3 & 2.0\end{array}$

33

33

44

39

33

29

26

29

39

33

31

33

37

36

30

37

32

36

35

37

39

32

34.5

$\begin{array}{ll}0.0 & 9.210 .0\end{array}$

9.210 .0
7.310 .8

$\begin{array}{lll}0.0 & 12.8 & 10.0\end{array}$

0.4

$6.28 .3 \quad 3.7$

$\begin{array}{ll}4.0 & 2.0\end{array}$

34

$\begin{array}{lllll}0.0 & 6.010 .0 & 4.7 & 2.3 & 37\end{array}$

$\begin{array}{lllll}0.0 & 6.310 .0 & 4.3 & 2.3 & 35\end{array}$

$\begin{array}{lllll}0.0 & 10.3 & 10.0 & 5.0 & 2.0\end{array}$

0.0

4.710 .0

$\begin{array}{ll}4.7 & 2.3\end{array}$

43 


\section{LEGENDS OF FIGURES}

Fig. 1. Correspondence analysis. Projection of plots and abundance of earthworm species along axis 1. Origin of the axis is indicated by an arrow. Higher values are in bold roman type, lower values are in italics. Variables significantly correlated with axis 1 are in boxes.

Fig. 2. Correspondence analysis. Projection of plots, litter and humus features, and height of tallest trees, along axis 1 . Origin of the axis is indicated by an arrow. Variables significantly correlated with axis 1 are in boxes.

Fig. 3. Correspondence analysis. Projection of plots, geomorpgology, and forest architecture, along axis 1 . Origin of the axis is indicated by an arrow. Variables significantly correlated with axis 1 have been encircled.

Fig. 4. Correlation between depth of the limestone layer and density of soil-dwelling earthworms. (S) means that blown sand lies directly on sandstone. Regression lines of ordinate versus abscissa have been drawn.

Fig. 5. Correlation between depth of the limestone layer and calcium content of beech leaf litter. (S) means that blown sand lies directly on sandstone. Regression lines of ordinate versus abscissa have been drawn.

Fig. 6. Correlation between depth of the limestone layer and height of tallest beech trees. (S) means that blown sand lies directly on sandstone. Regression lines of ordinate versus abscissa have been drawn.

Fig. 7. Correlation between densities of soil-dwelling earthworms and height of tallest beech trees. Regression lines of ordinate versus abscissa have been drawn. 


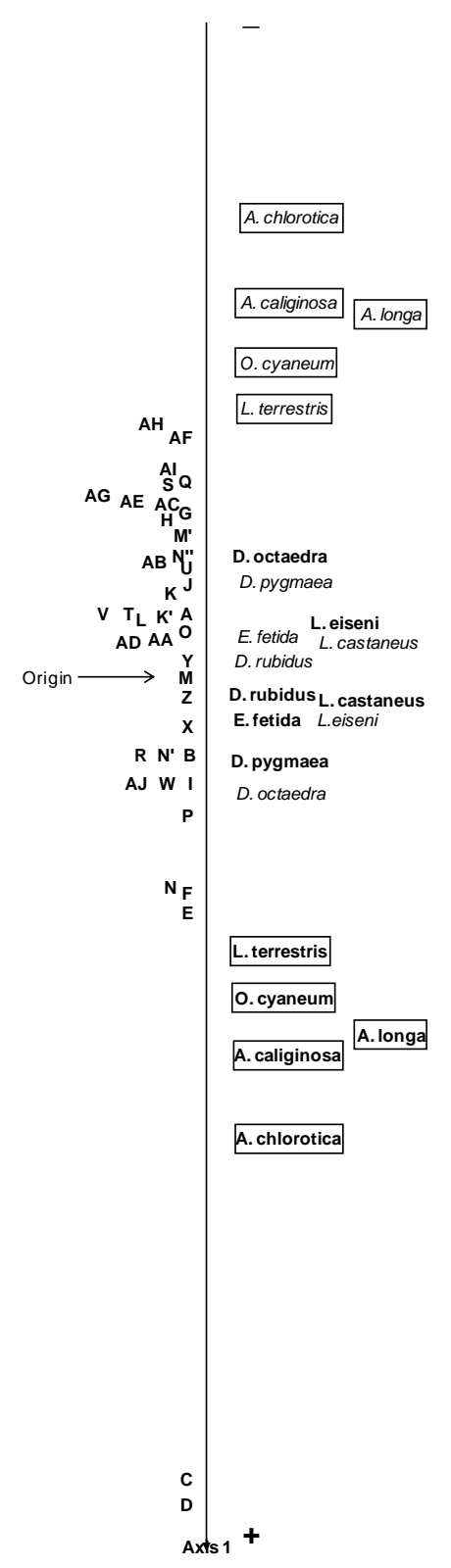

Fig. 1

3 


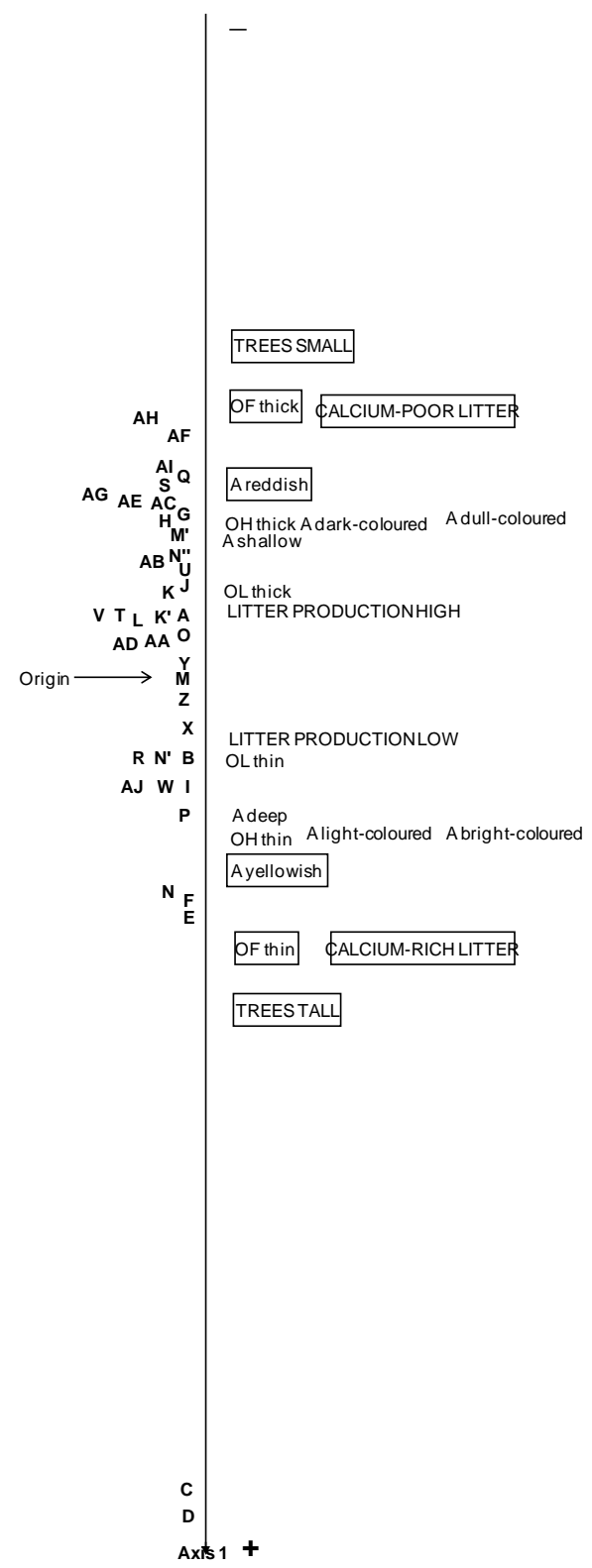

Fig. 2

3 


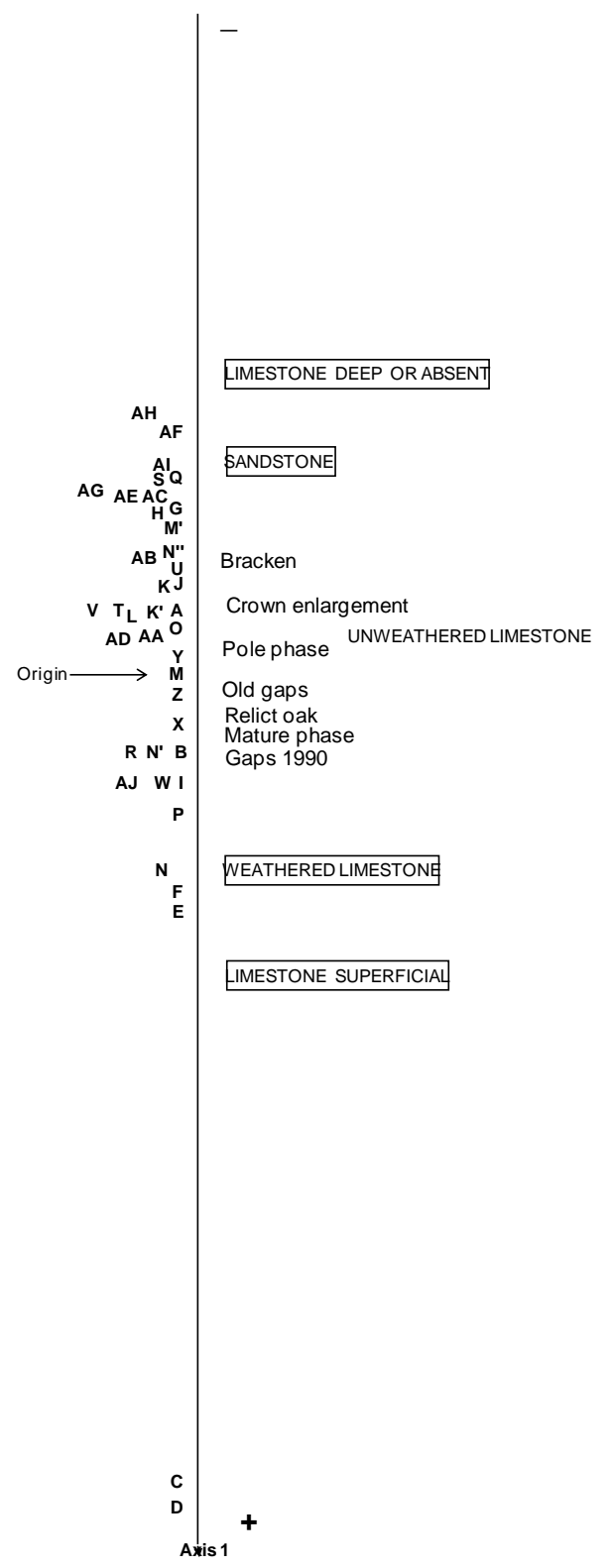

2 Fig. 3

3 


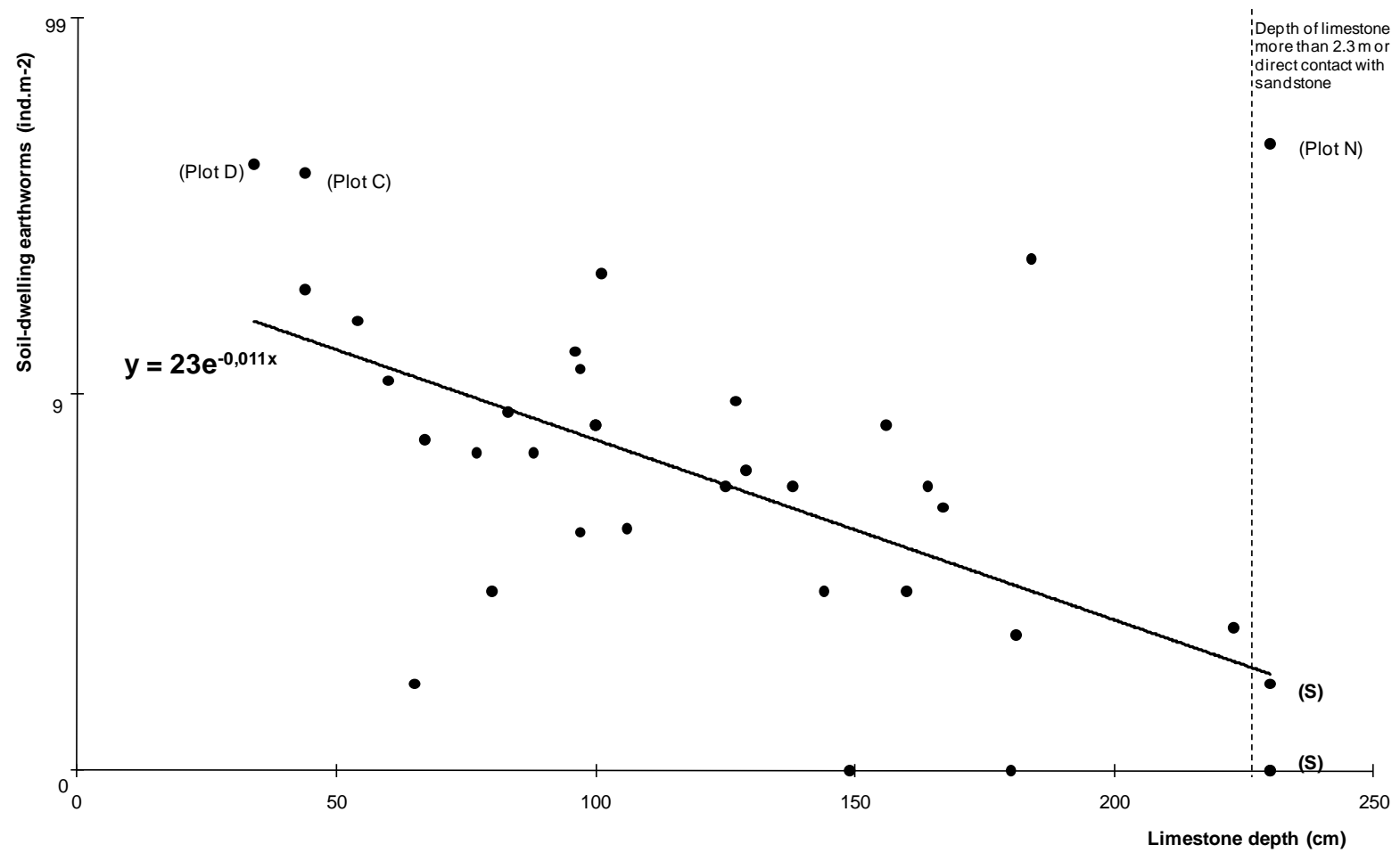

Fig. 4

3 


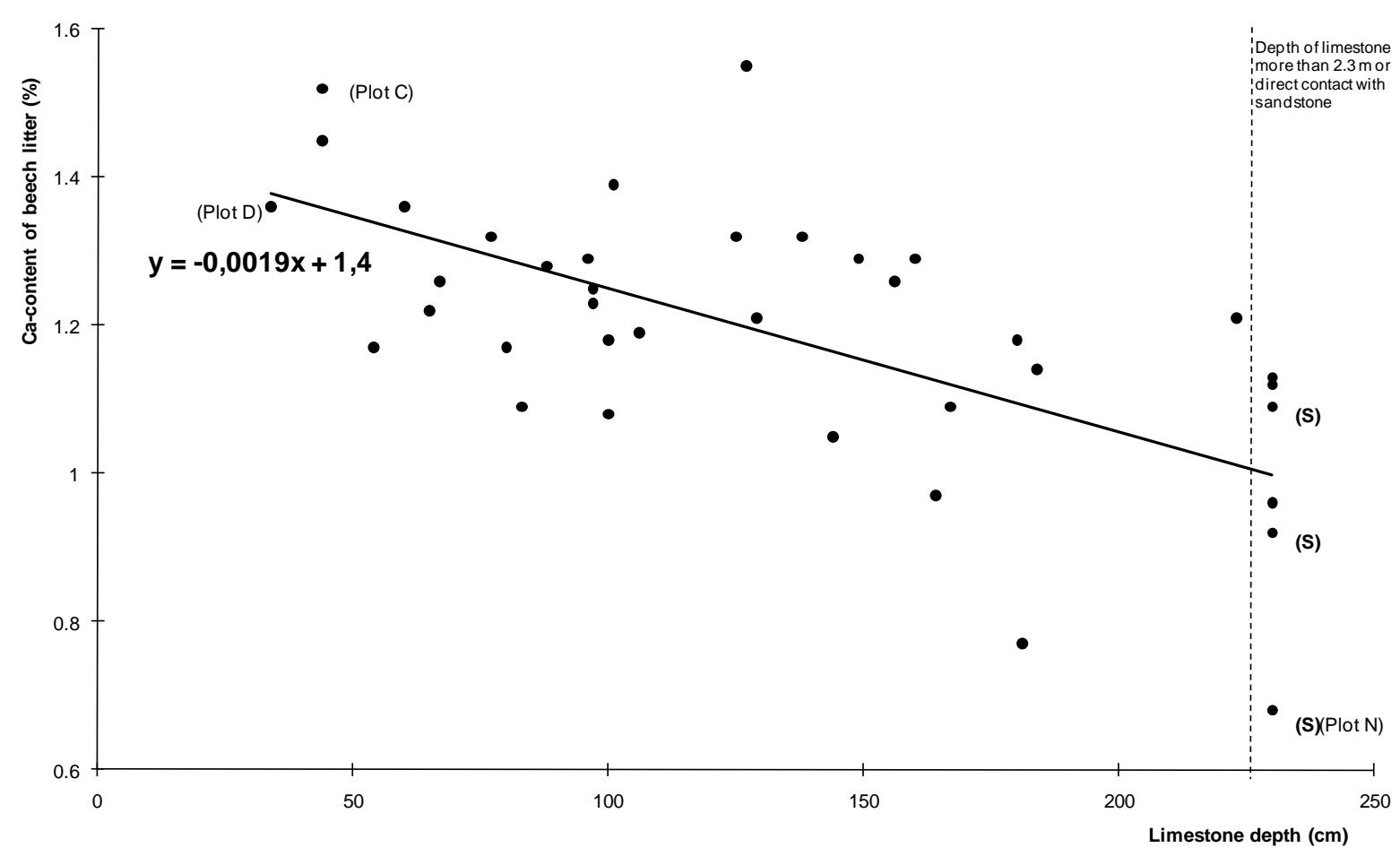

Fig. 5

3 


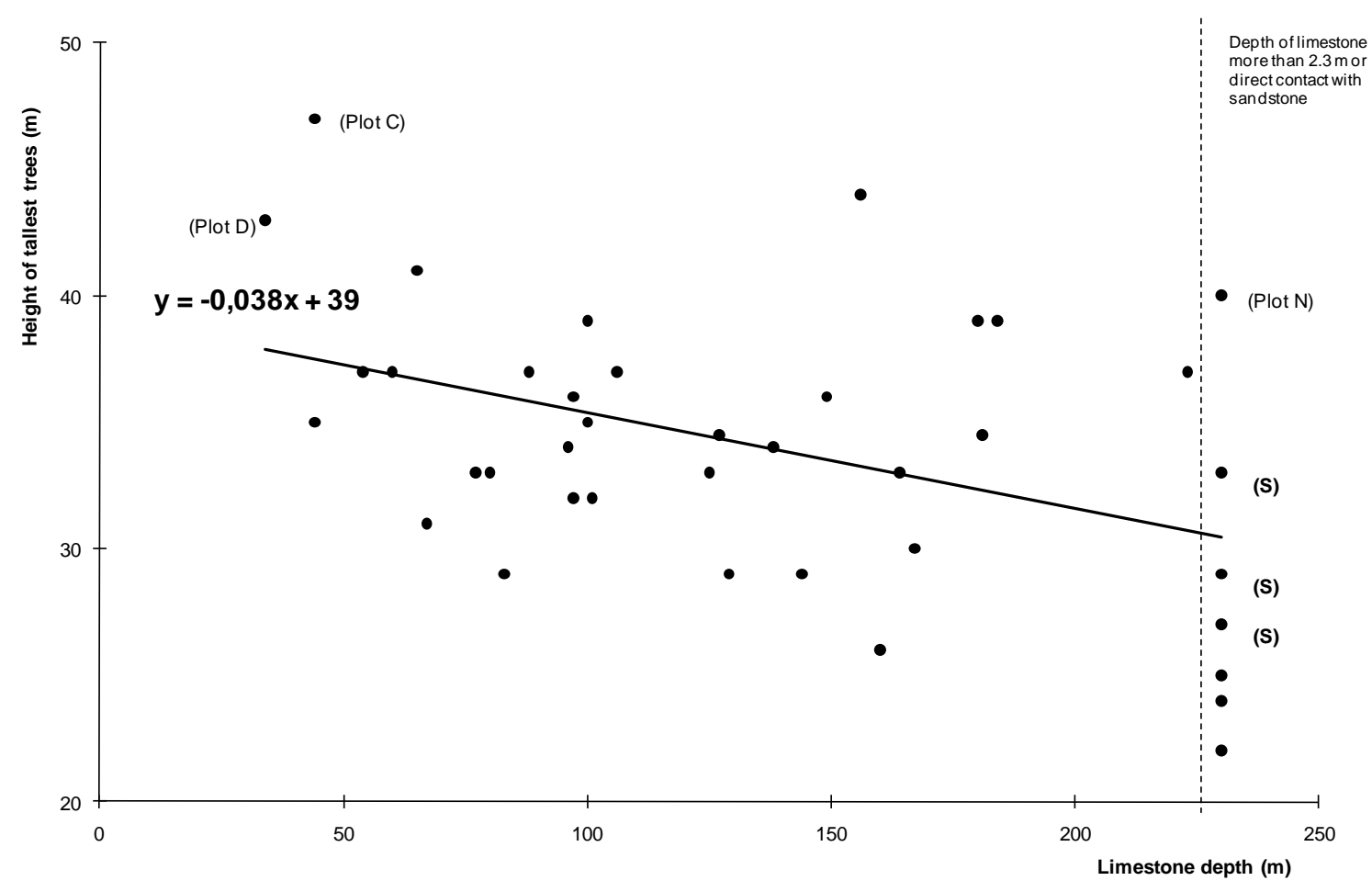

Fig. 6

3 


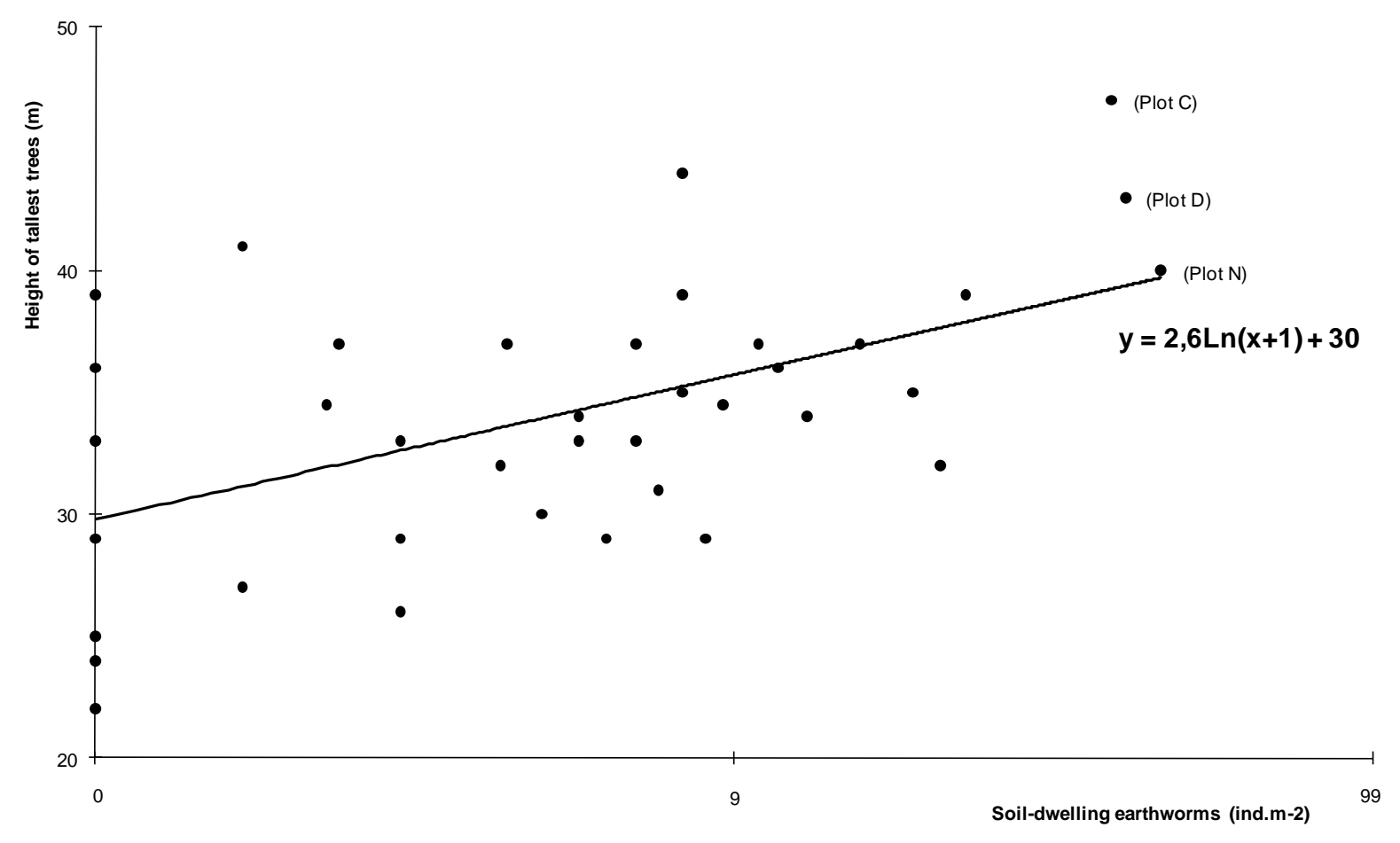

Fig. 7 